\title{
CONSUMIR E SER CONSUMIDO, NOVOS OLHARES SOBRE A RELAÇÃO ENTRE HOMENS E ANIMAIS NA LITERATURA LATINO-AMERICANA CONTEMPORÂNEA ${ }^{1}$
}

\author{
TO CONSUME AND TO BE CONSUMED, NEW PERSPECTIVES \\ ABOUT THE RELATION BETWEEN HUMANS AND ANIMALS IN \\ THE CONTEMPORARY LATIN AMERICAN LITERATURE
}

\author{
Maíra Soalheiro Grade ${ }^{2}$ \\ [https://orcid.org/0000-0002-7341-0436] \\ Kelly Luciana Bueno 3 \\ [https://orcid.org/0000-0003-0586-0723] \\ Antonio Rediver Guizzo 4 \\ [http://orcid.org/0000-0002-6583-8205] \\ DOI: 10.30612/raido.v14i35.11041
}

RESUMO: A Ecopolítica pode ser compreendida como um novo campo de produçăo de poder/saber relacionado a tecnologias de governo do planeta que incidem nas relaçóes entre capitalismo eambiente entre democracia egestăo do planeta. Uma das dimensôes que participam da Ecopolítica é a afirmaçăo, expansăo e consolidaçâo dos direitos dos animais como fundamento da coexistência ética das espécies, sobretudo através da problematizaçấo da fronteira entre humanidade/animalidade. Paralelamente ao desenvolvimento da Ecopolítica, também se destaca a contínua inserçăo do Estado de Exceçâo como forma contemporânea de governo, limiar de indistinçáo entre direito e violência sob a qual qualquer cidadáo pode ser elevado à categoria de homo sacer (Agamben, 2002). Essas sâo as duas dimensôes que constituem a obra distópica Cadáver Exquisito (2018) da escritora argentina contemporânea Agustina Bazterrica. Neste artigo, pretendemos analisar como se figuram no romance da autora: a) a legitimaçáo do estado de exceçấo; e b) a fronteira humanidade/animalidade e as dimensôes da ecopolítica que estruturam o romance. Para tal fim, utilizamos como aportes teóricos

O presente artigo é resultado das pesquisas realizadas no âmbito do projeto de pesquisa Imaginários da Violência na Literatura Latino-Ämericana, financiado pelo Programa de Infraestrutura para Jovens Pesquisadores - Programa Primeiros Projetos - PPP (Acordo CNPq/Fundaçáo Araucária), e das pesquisas realizadas no Grupo de Pesquisa Imaginários Latino-Americanos(ILA), financiadopelo Programa Institucional de Apoio aos Grupos de Pesquisa da Universidade Federal da Integraçăo Latino Americana (UNILA).

2 Mestre em Políticas Públicas e Desenvolvimento pela Universidade Federal da Integraçăo LatinoAmericana pela Universidade Federal da Integraçấo Latino-Americana (UNILA). Graduada em Direito pela Universidade Estadual do Oeste do Paraná (UNIOESTE).

3 Mestranda bolsista da CAPES no Programa de Pós-Graduaçáo em Literatura Comparada da Universidade Federal da Integraçáo Latino-Americana (UNILA). Graduada em Secretariado Executivo pela Universidade Estadual do Oeste do Paraná (2016).

4 Doutor em Letras pela Universidade Estadual do Oeste do Paraná (2014). Professor Adjunto da Universidade Federal da Integraçăo Latino-Americana (UNILA 
Giorgio Agamben, Peter Sloterdijk, Michel Foucault, Gabriel Giorgi entre outros. A partir da análise, observamos que a problematizaçâo da diferença ontológica entre humano e animal, no romance, aponta à tendência contemporânea de humanizaçáo do segundo, elevado à vida qualificada, enquanto, na relaçăo entre seres humanos, ainda se destaca a definiçăo e normatizaçăo dos contornos do humano, relegando à dimensăo da vida nua aqueles que excedem tais margens.

Palavras-chave: Literatura Latino-Americana Contemporânea; Agustina Bazterrica; Ecopolítica; Estado de Exceçăo.

ABSTRACT: Ecopolitics can be understood as a new field of production of knowledge and power related to government technologies of the world that affect relations between capitalism and environment and between democracy and the management of the planet. One of the dimensions of the Ecopolitics is the statement, expansion and consolidation about animals rights as the basis on the ethical coexistence of the species, mainly the discussions of the frontier between humanity/animality. All the same time the Ecopolitics development, there is also the continuous insertion of State of Exception as a contemporary form of government, indistinction limit between law and violence that can turn any citizen into homo sacer (Agamben, 2002). Those are two constitute dimensions the dystopian book Cadáver Exquisito (2018) of the contemporary Argentine writer Agustina Bazterrica. In this article, we intend to analyse as they appear in the author's novel: a) The State of Exception legitimation; and b) Frontier between humanity/animality and the dimension of ecopolitics in the novel. For this purpose, we used theoretical contributions as Giorgio Agamben, Peter Sloterdijk, Michel Foucault, Gabriel Giorgi and others. From the novel analysis, we observed that the problematization of the ontological difference between human and animal points to a contemporary trend of animal humanization, when animals are elevated to a qualified life. Meanwhile, in the relationship between human beings, the definition and standardization of the boundaries of what is human are highlighted, and those who exceed such frontiers are relegated to a bare life.

Keywords: Contemporary Latin American Literature; Agustina Bazterrica; Ecopolitics; State of Exception.

\section{INTRODUÇÃO}

26. Entăo Deus disse: "Façamos o homem à nossa imagem e semelhança. Que ele reine sobre os peixes do mar, sobre as aves dos céus, sobre os animais domésticos e sobre toda a terra, e sobre todos os répteis que se arrastem sobre a terra."

$[\ldots]$

28. Deus os abençoou: "Frutificai, disse ele, e multiplicai-vos, enchei a terra e submetei-a. Dominai sobre os peixes do mar, sobre as aves dos céus e sobre todos os animais que se arrastam sobre a terra" (BÍBLIA, Gênesis, 1, 26-28).

O Gênesis, mito de fundaçâo da tradiçấo religiosa judaico-cristă, carrega a fronteira demarcatória que orienta a relaçăo entre homem e natureza no ocidente: de um 
lado, o homem, aquele que foi criado à imagem e semelhança de Deus; do outro, os seres que representam a alteridade, a diferença fundante que constitui a dicotomia humanidade/animalidade; de um lado, o soberano; do outro, os dominados. Em outras palavras, a tradiçâo judaico-cristă funda o processo de subjetivaçăo no qual a natureza humana - divina, visto ser imagem e semelhança de Deus - constitui-se a partir da diferença dos outros seres vivos e a partir do direito (dado pelo próprio Deus) de reinar sobre a terra e sobre tudo o que nela habita. A contrapartida humana a essa distinçấo do Criador seria a missâo de erguer sobre a terra um reino à imagem do reino dos céus.

Outro pilar constitutivo da diferença entre humanidade/animalidade encontramos na divisăo entre zoé e bíos estabelecida por Aristóteles (384 a. C. - 322 a. C.) na obra Política. Zoé é a vida circunscrita à simples presença corporal no mundo, reduzida às exigências e aos imperativos biológicos em sua mais simples e natural ordem (o mero fato de viver compartilhado entre animais e homens). Bíos, por sua vez, é a forma qualificada de estar no mundo - a vida náo determinada pela natureza (como no caso dos outros animais), mas passível de transformaçăo através do logos. O homem, o único ser capaz de dar forma à própria existência, ultrapassa o mero fato de viver (zoé) e constrói um modo de viver (bíos). Por isso, para Aristóteles, o homem é o animal político, o único capaz de, por meio da palavra (logos), conceber uma existência ética.

É evidente que o homem é o animal mais político do que as abelhas ou qualquer outro ser gregário. A natureza, como se afirma frequentemente, năo faz nada em văo, e o homem é o único animal que tem o dom da palavra. E mesmo que a mera voz sirva para nada mais do que uma indicaçáo de prazer ou de dor, a relaçăo entre elas e năo mais que isso, o poder da palavra tende a expor o conveniente e o inconveniente, assim como o justo e o injusto. Essa é uma característica do ser humano, o único a ter noçăo do bem e do mal, da justiça e da injustiça. E é a associaçăo de seres que têm uma opiniăo comum acerca desses assuntos que faz uma família ou uma cidade (ARISTÓTELES, 1999, p. 146).

A imagem bíblica encontramos recuperada e expandida séculos mais tarde em John Locke (1632 - 1704), o pai do liberalismo, na obra Segundo tratado sobre o governo civil: ensaio sobre a origem, os limites e os fins verdadeiros do governo civil (1689).

A terra e tudo o que ela contém foi dada aos homens para o sustento e o conforto de sua existência. Todas as frutas que ela naturalmente produz, assim como os animais selvagens que alimenta, pertencem à humanidade em comum, pois săo produçăo espontânea da natureza (1994, p. 97).

A relaçâo entre homem e natureza, para Locke, é fundamentada pela noçâo de jusnaturalismo, forma de compreensăo jurídica que propóe como fonte legítima da lei os direitos naturais e universais, imutáveis e invioláveis, emanados do estado de natureza. Ou seja, a fonte do direito do homem sobre as demais espécies está acima do próprio homem, de sua vontade e de suas leis, é natural, assim como as leis físicas que regem o movimento dos astros.

Esta natureza, como depreendemos na citaçăo, deriva da condiçăo privilegiada do homem, ser feito à imagem e semelhança de Deus. Logo, naturalmente superior, cabe ao outro (animais e natureza) responder também a um desígnio divino: o sustento e o conforto da existência humana. 
A expansăo promovida por Locke é a inclusăo da ideia liberal de propriedade. A terra e os animais ("criaturas inferiores") pertencem em comum a todos os humanos, entretanto cada pessoa é proprietária de si. Logo, sendo o homem dono de si, também é proprietário de sua força de trabalho, em consequência, é igualmente proprietário de tudo aquilo que é transformado pelo emprego dessa força que lhe pertence - "o trabalho de seu corpo e a obra produzida por suas máos săo propriedade sua. Sempre que ele tira um objeto do estado em que a natureza o colocou e deixou, mistura nisso o seu trabalho e a isso acrescenta algo que lhe pertence, por isso o tornando sua propriedade" (LOCKE, 1994, p. 98).

A divisăo aristotélica, por sua vez, é retomada por Giorgio Agamben em Homo sacer - Il potere sovrano e la nuda vita I (1995) quando, ao investigar a lacuna deixada por Michel Foucault sobre a interseçăo entre o modelo jurídico-institucional e o modelo biopolítico do poder, traz à luz uma categoria-funçâo essencial na política moderna: a vida nua, a vida matável e insacrificável do homo sacer - "Uma obscura figura do direito romano arcaico, na qual a vida humana é incluída no ordenamento unicamente sob a forma de sua exclusâo (ou seja, de sua absoluta matabilidade)" (AGAMBEN, 2002, p. 16).

Nesse ponto, ao lado das tecnologias disciplinares das instituiçôes (escola, caserna, hospital psiquiátrico, fábrica e prisôes) e das formas de moldagem da sociedade de controle por meio das quais o Estado integra à sua esfera de atuaçăo o cuidado da vida e dos corpos dos indivíduos (a inclusão da zoé na política), Agamben localiza os processos de inclusâo da vida nua pela paradoxal figura do abandono.

Aquele que foi banido năo é, na verdade, simplesmente posto fora da lei e indiferente a esta, mas é abandonada por ela. Ou seja, exposto e colocado em risco no limiar em que vida e direito, externo e interno, se confundem. Dele náo é literalmente possível dizer que esteja fora ou dentro do ordenamento (AGAMBEN, 2002, p. 36).

Assim, enquanto Foucault observava mais detalhadamente a ambivalência do poder disciplinar que integra a zoé à política - ao mesmo tempo em que sujeita o indivíduo (polo negativo), adestra e produz comportamentos e resultados positivos (saúde, segurança, educação) -, e destaca que sua principal funçáo é a inclusâo dos indivíduos no sistema normalizador.

A fábrica năo exclui os indivíduos; liga-os a um aparelho de produçăo. A escola năo exclui o indivíduo; mesmo fechando-os, ela o fixa a um aparelho de transmissáo do saber. O hospital psiquiátrico năo exclui os indivíduos; liga-os a um aparelho de correçăo, a um aparelho de normalizaçaáo dos indivíduos [...] (FOUCAULT, 2002, p. 114).

Agamben volta-se, sobretudo, para a contínua inserçāo do Estado de Exceçâo como forma contemporânea de governo, limiar de indistinçăo entre direito e violência sob a qual qualquer cidadáo pode ser elevado à categoria de homo sacer. Em outras palavras, Agamben investiga um exercício soberano do poder para o qual os indivíduos nâo estăo mais somente colocados sob a égide de mecanismos disciplinares que, em última instância, visam a um movimento inclusivo; mas à mercê da exclusăo sem disciplina, do abandono, da decisâo soberana sobre a vida matável - " [...] ponto em que a decisấo sobre a vida torna-se decisăo sobre a morte, e a biopolítica pode deste modo converter-se em tanatopolítica" (AGAMBEN, 2002, p. 128). 
Nesse móvel espaço entre bio e tanatopolítica, outro interessante ponto a se refletir é como tais dimensóes do político extrapolam o controle das vidas humanas e se infiltram no domínio de outras vidas (uma forma de ecopolítica). Contemporaneamente, sob esse eixo, o animal passa, de forma gradativa, a integrar politicamente o mundo. Antes reduzido a uma dimensâo utilitária e matável (reduzido à vida nua), o animal (sobretudo algumas espécies) torna-se vida qualificada (bíos), para a qual inclusive a proteçâo jurídica se estende em variadas circunstâncias. Assim, podemos observar, de um lado, o acirramento e desenvolvimento técnico da tanatopolítica na contemporaneidade sobre os corpos humanos (como observa Achille Mbembe em Necropolítica [2018] ao pontuar como se desenvolvem tecnologias de destruiçáo capazes de criar "mundos de morte"); de outro, os animais gradativamente deixam de ser corpos que se reservam à exploraçăo, à coisificaçâo, ao abandono, à eliminaçăo.

Entretanto, enquanto a problematizaçâo da diferença ontológica entre humano e animal opera predominantemente por meio da humanizaçâo do segundo; a cisâo humanidade e animalidade continua operante na relaçăo entre humanos e perpassa o imaginário social como forma de divisăo entre vidas humanas a proteger e vidas humanas a abandonar. Isto é, o outro humano, a alteridade năo assimilada, continua a ter a sua diferença marcada por meio procedimentos discursivos que constituem um saber-poder orientado à definiçăo e normatizaçâo dos contornos do humano, relegando à dimensâo da animalidade aquilo que excede tais margens. Assim, a negaçâo da humanidade a certos grupos sociais continua a produzir indivíduos desprotegidos, deslegitimados em suas diferenças culturais e desamparados juridicamente, indivíduos submetidos a um permanente estado de exclusăo e ilegalidade, a um estado de exceçăo.

\begin{abstract}
O outro social será o outro racial, mas também de outra espécie: esse é o terreno em que opera a biopolítica moderna; o animal e o "outro racial" (e a partir dali o outro sexual e de gênero) definiram o terreno em que os sonhos civilizatórios traçaram as distribuiçōes entre pessoa e năo pessoa, entre bíos/zoé, quer dizer, as distribuiçóes entre as vidas por proteger e as vidas por explorar; entre as vidas propriamente humanas e as vidas por subordinar, por explorar, por coisificar, e por eliminar - as vidas que se vendem e se compram nos mercados globais ou as vidas elimináveis na nova ordem política (GIORGI, 2016, p. 70).
\end{abstract}

Sobre esse horizonte, Peter Sloterdijk aponta para a falência do humanismo enquanto projeto civilizatório. Para Sloterdijk (2018), a mais perniciosa das práticas da metafísica europeia foi definir o ser humano como um animal racional, uma animalidade expandida por adiçôes espirituais, um animal influenciável sobre o qual o humanismo (as leituras humanistas) opera na disputa entre tendências bestializadoras e tendências domesticadoras. Conforme o filósofo, tal movimento, operado através do ensino com leitura compulsória dos clássicos, estrutura os três fracassos do humanismo: o cristianismo, o marxismo e o existencialismo, e parte de uma premissa em si disruptiva: uns săo objetos da produçáo do humano e outros decidem sobre as formas de produçáo do humano a partir da legitimaçăo discursiva de um saber-poder.

Neste artigo, partindo das consideraçôes acima, analisamos o romance distópico Cadáver Exquisito (2017) de Agustina Bazterrica, vencedor do prêmio Clarín em 2017. A análise estrutura-se a partir dos seguintes eixos: a) a legitimaçăo do estado de exceçấo; e b) a fronteira humanidade/animalidade e as dimensôes da ecopolítica que estruturam o romance. 


\section{APONTAMENTOS INICIAIS SOBRE A OBRA CADÁVER EXQUISITO}

Agustina María Bazterrica nasceu em Buenos Aires em 1974. Licenciada em Artes pela Universidade de Buenos Aires, atualmente trabalha como gestora e curadora no ciclo de arte Siga al Conejo Blanco, projeto que reúne uma vez por mês escritores e leitores para o debate de obras artísticas e literárias. Também oferece oficinas de escrita e coordena oficinas de literatura com a também escritora Agustina Caride. Entre as obras da autora, podemos destacar o romance Matar a la niña (2013), o livro de contos Antes del encuentro feroz (2016) e, no final de 2017, seu mais recente romance, Cadáver Exquisito, narrativa distópica vencedora do Prêmio Clarín de Novela, um dos principais prêmios literários da Argentina.

Em Cadáver Exquisito, um vírus, letal aos seres humanos, afeta a todos os animais do planeta, obrigando ao sacrifício de todas as demais espécies para evitar o contágio. Com a impossibilidade do consumo de carne, vários artigos científicos sâo publicados ensinando a populaçâo a suprir a falta de proteína; entretanto, outros estudos afirmam que a proteína vegetal é insuficiente para a sobrevivência da populaçâo. O governo é pressionado pela indústria milionária da proteína animal, que está sem funcionamento, e, sobretudo, pela histeria coletiva que se instalou na populaçăo com o medo da extinçăo da espécie. Os primeiros casos de canibalismo săo anunciados pela imprensa. Como uma tentativa de restabelecer a ordem social, o governo decide, apoiado em estudos científicos, legalizar a criaçâo, reproduçâo e consumo de carne humana. Os primeiros destinados para consumo săo os pobres, imigrantes e marginais e, com o tempo, humanos começam a ser reproduzidos através de inseminaçăo artificial para a alimentaçâo dos demais. $O$ processo de adaptaçăo dos frigoríficos, as novas regulamentaçôes e a criaçăo desse novo hábito alimentar é chamado de "Transiçấo". A resistência inicial de parte da populaçăo através de manifestaçôes e greves de fome săo, gradativamente, silenciadas, e se instala uma nova realidade social, na qual os humanos se dividem entre consumidores e consumidos (categorias nem sempre estanques, visto que virar "produto" é uma das penas infligidas àqueles que desobedecem às leis e às normas estatais). O canibalismo é ressignificado e a carne humana passa a ser chamada de "carne especial". Aqueles destinados ao consumo perdem a liberdade e a identidade e passam a ser chamados de produtos, cabeças, alimentos, fêmeas ou machos. Além de destinados à alimentaçấo, as "cabeças" passam a ser utilizadas como cobaias em experimentos científicos e, também, como fonte de entretenimentos.

A narrativa acompanha o protagonista do romance, Marcos Tejo, que trabalha num dos principais frigoríficos da Argentina. Ao lado do contexto social, somos apresentados aos dilemas pessoais do personagem: a internaçáo do pai em um hospital geriátrico, a morte do único filho, a esposa que o deixa e retorna para a casa dos pais, e o constante questionamento sobre a existência ou inexistência do vírus. No frigorífico, Marcos é responsável pela seleçăo e compra das melhores "cabeças" e pela garantia de qualidade no processo de abate e no fornecimento da melhor "carne especial" aos clientes.

Certo dia, Marcos recebe de um fornecedor, como forma de agradecimento pelo contrato fechado, uma "fêmea PGP", isto é, uma mulher cuja carne nâo recebeu nenhuma alteraçâo genética e, por isto, é considerada uma das melhores carnes do mercado. Legalmente, Marcos pode matar a fêmea para consumo, vendê-la, criá-la ou inseminá-la artificialmente, mas ele năo tem coragem de realizar nenhuma dessas açôes. Marcos 
começa a se envolver afetivamente e ter relaçôes sexuais com a fêmea; ato proibido, para o qual a puniçáo é a pena de morte (transformar-se em "produto").

Marcos começa a chamá-la de Jazmín e a ensina o uso de alguns objetos. Como as cordas vocais das "cabeças" sâo retiradas logo após o nascimento, Jazmín năo pode falar, e a comunicaçăo entre os dois é apenas gestual. Marcos a mantém dentro de casa, vigiada por câmeras. Jazmín engravida e, um dia, ao chegar em casa, Marcos percebe sua expressâo de dor e observa um líquido marrom escorrendo entre suas pernas. Sem poder levá-la a um hospital, Marcos chama a esposa, que é enfermeira, para auxiliá-lo no parto. Cecília (sua esposa), embora sabendo que também seria submetida a mesma pena se fossem descobertos, decide ajudá-lo. Jazmín dá à luz um bebê saudável. Amarrada à cama, ela tenta desesperadamente se soltar e pegar o filho. Marcos busca uma marreta e acerta um golpe preciso na fronte dela. Jazmín morre, e Cecília lamenta, dizendo que poderiam ter a usado para ter mais filhos. Cecília e Marcos decidem criar o filho de Jazmín no lugar do filho que perderam. O romance termina com a ambígua declaraçâo de Marcos sobre Jazmín: “Tenía la mirada humana del animal domesticado" (BAZTERRICA, 2018, p. 249).

\section{LEGITIMAÇÃO DA NECESSIDADE}

O fracasso das ideologias e utopias no século XX também marcou a decadência de um ciclo de obras literárias que mantinham certo caráter utópico, narrativas que, de diferentes formas, tematizavam e apostavam no progresso, na revoluçấo, no advento de um futuro de justiça social e paz. No lugar, ascenderam um conjunto de obras literárias distópicas, caracterizadas pela figuraçâo de cenários calamitosos nos quais o controle da linguagem e dos corpos, o ordenamento jurídico sob permanente estado de exceçấo, a violência institucional autorizada, a exclusăo de grupos sociais e, sobretudo, o medo, sâo utilizados como técnicas para a manutençăo da coesăo social de uma populaçăo pauperizada e reprimida. Contemporaneamente, como observa Leyla Perrone-Moisés (2016), as obras distópicas, tendencialmente, deixaram de tematizar somente os grandes sistemas políticos (comunismo, socialismo, liberalismo democrático) e se voltaram a ideologias mais circunscritas, tais como o feminismo, o transgenerismo sexual, o comunitarismo, o ecologismo, o vegetarianismo etc.

A obra Cadáver Exquisito de Agustina Bazterrica pertence a esse segundo grupo e, evidentemente, discute a relaçăo entre humanos e animais sob a chave do vegetarianismo. Entretanto, a construçăo ficcional da obra também leva à problematizaçâo de dimensóes políticas mais abrangentes, tais como a suspensăo de direitos, o exercício ilimitado da soberania, a marginalizaçăo de grupos sociais, a violência institucional e outras questóes que refletem a atual relaçăo entre a noçăo de Estado de Exceçăo e formas de governo contemporâneas.

Giorgio Agamben, em Estado de Exceçâo (2004), define o conceito jurídico-político como uma zona de indeterminaçăo entre o que está dentro e fora do Direito e destaca nas açôes políticas dos estados modernos iniciativas que visam suspender a ordem legal sob o pretexto de promover a coesâo social e a segurança jurídica dos cidadăos. Entre as origens do termo, Agamben (2004) destaca o decreto da Assembleia Constituinte de 08 de julho de 1791 da Revoluçáo Francesa, o qual diferenciava o Estado de Paz (État 
de Paix), quando as autoridades civis e militares deveriam agir somente nas devidas esferas de atuaçâo, o Estado de Guerra (État de guerre), em que as autoridades militares possuíam a prerrogativa de submeter as autoridades civis e os próprios cidadáos às suas determinaçōes, e o Estado de Sítio (État de Siège), em que todas as funçôes das autoridades civis passariam a ser responsabilidade das autoridades militares. Para Agamben (2004), o Estado de Sítio, a extensăo aos militares dos poderes civis, e a suspensâo dos direitos, garantias e liberdades individuais dos cidadăos, características de um Estado de Guerra, convergem, contemporaneamente, no Estado de Exceçâo, na suspensăo provisória e, por vezes, circunscrita, do regime democrático justificada pelo pretexto de salvaguarda da própria democracia. Para o autor, essa técnica de governo perde o caráter de excepcionalidade e "o estado de exceçấo tende cada vez mais a se apresentar como o paradigma de governo dominante na política contemporânea" (2004, p. 13). E é nesse sentido que Agamben define o totalitarismo moderno como

[...] a instauraçăo, por meio do estado de exceçăo, de uma guerra civil legal que permite a eliminaçăo física năo só dos adversários políticos, mas também de categorias inteiras de cidadăos que, por qualquer razăo, pareçam năo integráveis ao sistema político. Desde entăo, a criaçăo voluntária de um estado de emergência permanente (ainda que, eventualmente, năo declarado no sentido técnico) tornouse uma das práticas essenciais dos Estados contemporâneos, inclusive dos chamados democráticos (2004, p. 13).

Nessa perspectiva, aponta Agamben, o Estado de Exceçăo contemporâneo é constituído a partir da figura da necessidade da proteçâo da coesăo social diante de casos de conflitos categorizados como extremos, momento em que a ilegalidade da exceçấo deixa de ser anômica e se constitui em nova ordem jurídica, caracterizando-se como uma zona ambígua e incerta em que "procedimentos de fato, em si extra ou antijurídicos, transformam-se em direito e onde as normas jurídicas se indeterminam em mero fato; um limiar portanto, onde fato e direito parecem tornar-se indiscerníveis" (AGAMBEN, 2004, p. 45). Entretanto, o ponto de maior contundência do Estado de Exceçâo na contemporaneidade é que "a necessidade se reduz, em última instância, a uma decisâo, como também aquilo sobre o que ela decide é, na verdade, algo indecidível de fato e de direito" (p. 47). Logo, a suspensăo do ordenamento jurídico que garante o Estado de Exceçăo, por fim, tende a se fundamentar em um juízo soberano.

A ideia da necessidade de se romper a ordem democrática e a ordem social para salvá-la é um dos pontos centrais sob os quais é constituída a trama do romance Cadáver Exquisito. Quando um vírus letal aos seres humanos é anunciado pela imprensa oficial, o medo é disseminado entre a populaçăo - "Recuerda cuando anunciaron la existencia de la CGB. La histeria masiva, los suicidios, el miedo" (BAZTERRICA, 2018, p. 16). Posteriormente, outro temor é instalado no campo alimentar - "Después de la CGB fue imposible seguir comiendo animales porque contrajeron un virus mortal para los humanos [...]" (p. 16).

A profusăo de notícias destoantes, as buscas noturnas por animais de rua, as pilhas de animais queimados vivos, os casos de canibalismo - "La prensa registró el caso de dos bolivianos desempleados que fueron atacados, descuartizados y asados por un grupo de vecinos [...]" (p. 18) -, o medo da extinçăo da espécie humana, a luta pela sobrevivência individual entre outros acontecimentos instalam o caos social. Ao lado da comoçâo social, inicia-se o lobby da milionária indústria da proteína, e o governo, sob o pretexto 
de restabelecer a ordem ameaçada, legaliza o abate de seres humanos para consumo, e a anomia se transforma em nova ordem jurídica sob a decisáo de um poder soberano que atua diretamente na vida nua dos cidadáos.

[...] En algunos países los inmigrantes empezaron a desaparecer en masa. Inmigrantes, marginales, pobres. Fueron perseguidos y, eventualmente sacrificados. La legalización se llevó a cabo cuando los gobiernos fueron presionados por una industria millonaria que estaba parada. Se adaptaron los frigoríficos y las regulaciones. Al poco tiempo los empezaron a criar como reses para abastecer la demanda masiva de carne (BAZTERRICA, 2018, p. 18).

Entretanto, a suspensăo de garantias individuais asseguradas pela democracia liberal năo se restringe ao âmbito dos consumidos. Os protestos em massa, as greves de fome, o posicionamento das organizaçōes em prol dos direitos humanos é reprimido - "[...] los que lo hicieron de manera pública fueron silenciados" (p. 19) - enquanto o mercado de carne humana cresce em ritmo acelerado. Paulatinamente, o direito de desobedecer, manifestar-se ou mesmo questionar o novo ordenamento é restringido e penalizado. Instala-se um governo sob a égide de um poder soberano em relaçăo ao qual todos os cidadăos sâo potencialmente produtos, governo que mantém a característica central de um regime totalitário: todos podem tornar-se homines sacri - "El zoólogo con mayor prestigio, que en sus artículos decía que el virus era un invento, tuvo un accidente oportuno" (p. 19). E para a soberania, como aponta Agamben, "Nâo a simples vida natural, mas a vida exposta a morte (a vida nua ou a vida sacra) é o elemento político originário [...] o fundamento primeiro do poder político é uma vida absolutamente matável, que se politiza através de sua própria matabilidade" (2002, p. 96).

Após o estabelecimento da nova ordem pela repressăo, inicia-se o processo de naturalizaçăo por meio da linguagem. Diversas palavras, como canibalismo, săo proibidas, e os seres humanos destinados ao consumo passam a ser chamados de "carne especial", "produto", "cabeça", "macho" ou "fêmea", proibindo-se qualquer forma de atribuiçấo de identidade.

Nadie los llama así [humanos], piensa, mientras prende un cigarrillo. Él no llama así cuando tiene que explicarle a un empleado nuevo cómo es el ciclo de la carne. Podrían arrestarlo por hacerlo, podrían incluso mandarlo al Matadero Municipal y procesarlo. Asesinarlo sería la palabra exacta, aunque no la permitida [...] (BAZTERRICA, 2018, p. 15).

A vigilância dos cidadăos também se torna constante, sobretudo àqueles que criam "cabeças" domésticas para consumo - "Cada tanto aparece por su casa un inspector de la Subsecretaría de Control de Cabezas Domésticas" (BAZTERRICA, 2018, p. 184). Para a criaçăo doméstica, há uma regulamentaçăo que deve ser estritamente obedecida. Pode-se criar para o consumo (inclusive por partes, com ela ainda viva), pode-se inseminá-la artificialmente com o auxílio de profissionais capacitados, pode-se vendê-la ou, por qualquer razăo, simplesmente matá-la. Entretanto, săo expressamente proibidas a escravizaçâo e as relaçōes afetivas e/ou sexuais. Na próxima seçáo, vamos partir desses dispositivos de inclusâo e exclusâo para discutir a fronteira entre animalidade e humanidade problematizada em Cadáver Exquisito. 


\section{HUMANIDADE VERSUS ANIMALIDADE: APONTAMENTOS SOBRE UMA ECOPOLÍTICA}

Em uma passagem da narrativa o protagonista relembra um caso, de quando ainda trabalhava para a Subsecretaria de Controle de Cabeças Domésticas, de uma fêmea que foi encontrada em uma caixa de madeira escondida debaixo da cama de um casal. Apesar das condiçōes deploráveis em que a fêmea se encontrava, năo era motivo suficiente para aplicaçấo de uma multa; no entanto, a esposa, em um momento de desespero, confessa que o marido tinha constantemente relaçōes sexuais com a fêmea. Após a comprovaçăo por exames, o homem foi condenado à morte.

[...] Tener sexo con una cabeza, gozarla, es ilegal y la condena es la muerte en el Matadero Municipal. El equipo especial fue a la casa y confirmó que la hembra había sido gozada "de todas las maneras posibles". El dueño, un hombre de unos sesenta ańos, fue condenado y lo mandaron directo al Matadero Municipal [...] (BAZTERRICA, 2018, p. 189).

Sob essa perspectiva de constante ameaça, a narrativa introduz a relaçáo de Marcos Tejo e Jazmín. O progressivo envolvimento do protagonista com a fêmea, nesse ponto, exerce duas funçôes: a) em um primeiro plano, intensificar o suspense narrativo através da exposiçấo crescente de Marcos Tejo a uma situaçăo que poderia transformá-lo também em produto; b) problematizar ao leitor a cisâo entre humanidade e animalidade.

Assim, superficialmente, a narrativa apresenta a sucessâo de transgressóes de Marcos Tejo: concede uma identidade à fêmea, chama-a de Jazmín; tira-a do cativeiro e a leva para dentro de casa; ensina-lhe a utilizar alguns instrumentos; envolve-se afetiva e sexualmente com ela; e, por fim, engravida-a. - "Si el inspector llega a descubrir que Jazmín está embarazada lo van a mandar al Matadero Municipal, pero, peor que eso, le van a sacar al hijo" (BAZTERRICA, 2018, p. 190).

O encadeamento progressivo desses acontecimentos, ficcionalmente, mantém o suspense narrativo e funciona como forma de fixar a atençâo do leitor na trama. Entretanto, o que nos interessa na análise é a funçăo problematizadora dessa estratégia composicional, que se subdivide em duas dimensôes: a) questionar o paradigma divisório entre humanos e animais; b) intensificar tal paradigma com a superposiçâo de outra cisâo: humanos consumidores versus humanos consumidos.

Em relaçăo à primeira dimensâo, o período que sucedeu a Segunda Guerra Mundial foi marcado pela intensa criaçáo de normas de direito internacional que visavam, sobretudo, à defesa dos direitos humanos. A inserçăo na ordem jurídica internacional de diversos mecanismos de preservaçăo e promoçăo dos direitos humanos decorreu do espírito do tempo que vigorava à época, em que evitar a ocorrência de novas perversidades como aquelas cometidas pelos regimes totalitários consistia em tema prioritário no plano global.

A Declaraçăo Universal dos Direitos Humanos, proclamada em 10 de dezembro de 1948 pela Assembleia Geral das Naçóes Unidas, apontou o reconhecimento da dignidade humana como pressuposto necessário à liberdade, à justiça e à paz no mundo, e estabeleceu, em seu preâmbulo, a necessidade do respeito universal aos direitos e liberdades humanas fundamentais. (ASSEMBLEIA GERAL DA ONU, 1948). 
Como decorrência do processo de efetivaçăo dos direitos humanos, observamos, nas últimas décadas, a criaçăo de vários Tratados Internacionais que possuíam como principal objetivo a proteçăo ao meio ambiente. Em outras palavras, amplia-se o espectro dos direitos humanos e, consequentemente, os tratados internacionais e os ordenamentos jurídicos dos Estados passam a incorporar dispositivos que reconhecem a vida em meio ambiente ecologicamente equilibrado como direito humano.

A Constituiçấo Federal de 1988, por exemplo, em vários de seus artigos, consagrou a defesa do meio ambiente como um de seus objetivos fundamentais. No Título II, que trata dos direitos e garantias fundamentais, no inciso LXXIII, estabeleceu a legitimidade de qualquer cidadâo para propor açăo popular a fim de anular quaisquer atos que possam causar lesăo ao meio ambiente (BRASIL, 1988).

Além disso, o texto constitucional também estabeleceu, no artigo 225, o dever, por parte do Poder Público, de defender e preservar o meio ambiente ecologicamente equilibrado para as presentes e futuras geraçôes. Para que fosse possível assegurar a efetividade desse direito, a Constituiçăo Federal estabeleceu que

[...] incumbe ao Poder Público:

I - preservar e restaurar os processos ecológicos essenciais e prover o manejo ecológico das espécies e ecossistemas;

$[\ldots]$

VII - proteger a fauna e a flora, vedadas, na forma da lei, as práticas que coloquem em risco sua funçăo ecológica, provoquem a extinçăo de espécies ou submetam os animais a crueldade. (BRASIL, 1988).

Essas e outras previsôes legais derivam da constituiçăo de um novo campo de produçâo de saber no qual as relaçôes entre capitalismo e ambiente e entre democracia e gestăo do planeta săo problematizadas. Na dimensăo capitalista, evidencia-se o surgimento da noçăo de desenvolvimento sustentável; na dimensăo político-legislativa, notabiliza-se a incorporaçấo da necessidade de proteçáo do ambiente à segurança da saúde (produçâo de corpo-espécie saudável), como também se destaca a segurança do ambiente como campo autônomo. Nesse ponto, poderíamos classificar como uma das dimensóes da ecopolítica todo um novo campo de produçâo de saber relacionado a tecnologias de governo do planeta, tecnologias essas que se desdobram transterritorialmente nos âmbitos político-legislativo (tratados internacionais) e capitalista (certificados de reduçấo de impacto ambiental que agregam valor ou preferência a determinados produtos).

Entretanto, o capitalismo verde e a noçâo de desenvolvimento sustentável nâo deixaram de estabelecer como principal alvo a elevaçăo dos indicadores econômicos, e a ideia de qualidade de vida e reduçâo de danos ambientais mantiveram-se adstritas a uma economia de concentraçâo de renda que afeta, sobretudo, os países em desenvolvimento. Ademais, também a qualidade de vida e a reduçâo de danos ambientais na dimensâo de uma governabilidade planetária privilegiaram os países do primeiro mundo e mantiveram praticamente intactos os ciclos de exploraçâo de recursos naturais e humanos dos países do terceiro mundo. Nesse campo, o que de fato globalizou-se foi a noçâo de participaçấo na gestăo do planeta, novo campo discursivo em que os 
cidadăos săo convocados (e responsabilizados) à gestăo e à preservaçăo do ambiente (cidadăos também facilmente cooptados pelas estratégias de marketing do capitalismo sustentável).

O surgimento do imaginário da responsabilidade individual pelo planeta se consolidou como uma nova tecnologia de controle da qual participam tanto um "ecocidadăo" quanto um capitalismo social e ecologicamente responsável ("com uma face mais humana"), ambos marcados por uma multiplicidade de motivaçōes manifestas em diferentes gradaçôes. Entre elas, interessa à discussăo, sobretudo, os direitos dos animais, campo de luta no qual as noçóes de "responsabilidade de", "dever de proteger a" e "garantir um futuro melhor às próximas geraçóes", se năo romperam a cisăo ocidental humano/animal, estenderam a dimensăo da humanidade (e seu bíos) a diferentes espécies e, em algumas gradaçóes, mais contemporaneamente, à totalidade das espécies.

No âmbito político-legislativo transterritorial, em decorrência, o surgimento da preocupaçăo global com o direito ao meio ambiente ecologicamente equilibrado também alavancou um movimento de cooperaçâo entre atores internacionais com o fim de estabelecer os animais como seres possuidores de direitos. A proteçáo dos animais relacionou-se diretamente à ideia da construçăo de um meio ambiente sustentável para as futuras geraçôes e também ao conceito de solidariedade entre os seres humanos e as demais espécies animais.

A efetivaçâo de um documento com alcance global reconhecendo a necessidade do cuidado com os animais, por exemplo, ocorreu por meio da proclamaçâo da Declaraçăo Universal dos Direitos dos Animais, no ano de 1978. A declaraçáo constituiu o início formal de uma era de afirmaçâo, expansâo e consolidaçăo dos direitos dos animais, por meio do reconhecimento, em seu preâmbulo, de que o direito à existência das outras espécies animais constitui o fundamento da coexistência ética no mundo. O documento assegurou ainda, em seu artigo 2 , que

O homem, enquanto espécie animal, năo pode atribuir-se o direito de exterminar os outros animais, ou explorá-los, violando esse direito. Ele tem o dever de colocar a sua consciência a serviço dos outros animais. Cada animal tem direito à consideraçấo, à cura e à proteçăo do homem. (ASSEMBLEIA GERAL DA ONU, 1978).

Aprofundando um pouco o âmbito da responsabilidade cidadă, ao lado dos documentos internacionais que reconhecem os direitos dos animais, constitui-se um campo de produçâo de saber de onde irrompem as teorias denominadas abolicionistas, que consideram năo haver nenhuma diferença entre vidas humanas e năo-humanas. Gary Francione (2010, p. 36), um dos principais autores abolicionistas, por exemplo, defende, entre outras coisas, a aboliçăo do estatuto legal dos animais como propriedade e, por consequência, o fim da produçâo pecuária e demais atividades que utilizam animais (produçăo de roupas, alimentos, pesquisas científicas etc.). Para o autor,

The fact that the minds of humans differ from nonhumans does not mean that the life of a human has greater moral value any more than it means that the life of a human who is 'normal' has greater moral value than does the life of a mentally disabled person or that the life of an intelligent person has greater moral value than does a 'normal' but less intelligent one. Although the differences between humans and animals may be important for some purposes, they are completely irrelevant to 
the morality of using and killing animals, even if we do so 'humanely'.5 (FRANCIONE, 2010, p. 34)

Em outras palavras, tanto a distinçăo aristotélica relacionada à capacidade cognitiva do ser humano quanto a noçâo de propriedade encontrada em John Locke nâo só săo questionadas e refutadas como redimensionadas ao âmbito da responsabilidade humana sobre os demais seres vivos, produzindo um campo ético antes inexistente na relaçăo humano/animal. Peter Singer, em Animal Liberation (1975), por exemplo, afirma que o mesmo princípio ético que assenta a igualdade entre os humanos deve abrigar nossa relaçấo com os animais, visto que "a defesa da igualdade năo depende da inteligência, da capacidade moral, da força física ou características semelhantes. A igualdade é uma ideia moral, e năo a afirmaçâo de um fato (SINGER, 2000, p. 4). Categorizando os animais como seres sencientes (capazes de vivenciar o sofrimento e a alegria), Singer destaca que "está na capacidade de sofrimento a característica vital que concede a um ser o direito a uma consideraçấo igual e nâo na faculdade da razâo ou na faculdade da linguagem ou do discurso (SINGER, 2000, p.7).

Ademais, esse novo campo do saber que produz um cidadăo ético, responsável e participativo, ao mesmo tempo, produz um cidadăo vigilante, e sua vigilância possibilita a efetivaçăo de uma segunda dimensăo da ecopolítica: uma tecnologia de controle ambiental, amplificada cada vez mais pela expansâo e desenvolvimento das redes sociais e outros instrumentos de difusăo de informaçôes, em que a populaçâo é disciplinada năo apenas pelas instituiçóes (escolas, hospitais, fábricas, caserna, prisăo etc.), mas por meio de controles contínuos, cada vez mais descentralizados e horizontais.

Essas sâo as condiçôes materiais que constituem Cadáver Exquisito. O romance, ao lado das reflexóes sobre os homines sacri, os abandonados pela sociedade - para a autora, o livro tem como principal objetivo promover espaços solidários de relaçâo com os outros através da literatura, mas "no es un alegato para dejar de comer carne, ni una forma de defender a los vegetarianos, el fanatismo es otra forma de violencia" (Bazterrica, 2019) -, também resulta do novo campo da produçăo de saber e das tecnologias de controle que constituem a ecopolítica. Em uma entrevista concedida ao programa Los sietes loucos da televisăo argentina em janeiro de 2018, Agustina Bazterrica afirma que é vegetariana e revela a sua relaçáo com a carne. “Dejé de comer carne gracias a las charlas que tuve con mi hermano que trabaja con comida orgánica. Yo empecé a cambiar mi alimentación, soy vegetariana, deje de comer carne y realmente se me corrió un velo, para mí un bife ahora es un cadáver." Em otras palabras, a humanizaçâo dos animais pela condiçáo de seres sencientes (capazes de sofrer) e a decorrente opçấo pelo vegetarianismo da autora também transparecem na composiçâo da obra.

O fato de as mentes dos seres humanos diferirem dos năo-humanos năo significa que a vida de um humano tenha maior valor moral, assim como nâo significa que a vida de um ser humano 'normal' tenha maior valor moral do que a vida de uma pessoa com deficiência mental ou que a vida de uma pessoa inteligente tenha maior valor moral do que uma vida 'normal', mas menos inteligente. Embora as diferenças entre humanos e animais possam ser importantes para alguns propósitos, elas sāo completamente irrelevantes para a moralidade de usar e matar animais, mesmo se o fizermos 'humanamente'. Traduçáo nossa. 
Segundo Bazterrica, a ideia do livro surgiu enquanto caminhava pelas ruas de Buenos Aires e passou por um açougue. Observando as carnes expostas para a venda, indagou-se: "¿se hay cadáveres de animales porque no puede haber cadáveres de humanos?", e movida por essa imagem iniciou o processo de pesquisa e escrita do romance. Para Agustina, o processo de investigaçăo foi doloroso, pois, para construir as descriçóes técnicas do abate, cortes da carne, entre outros processos, a escritora examinou exaustivamente vídeos técnicos da indústria frigorífica - "Vi muchos videos institucionales. Me acuerdo uno que solo era la parte de tripería, como trabajan con las tripas" (BAZTERRICA, 2018).

E sâo essas passagens técnicas do processo transplantadas ao contexto do romance que causam ao leitor o maior desconforto, como a descriçăo, nas primeiras páginas, da vida dos humanos destinados ao consumo - "[...] El Gringo le contesta que desde chiquitos los aíslan en incubadores y después en jaulas. Que les sacan las cuerdas vocales y así los pueden controlar más. Nadie quiere que hablen porque la carne no habla [...." (BAZTERRICA, 2018, p. 32). Assim como no caso dos animais, também esses humanos vivem em cativeiro durante toda a vida, e deles sáo explorados todos os recursos possíveis. Em relaçăo às fêmeas, por exemplo, algumas săo destinadas à maternidade, outras à ordenha (como o processo de ordenhamento e procriaçăo é exaustivo e estressante, possuem uma vida útil curta e, quando já năo săo mais úteis, a carne é vendida mais barata aos fast foods, maximizando todas as possibilidades de lucro). O ciclo de reproduçāo é tăo desumano, que algumas fêmeas tentam romper a gestaçāo, essas têm seus braços e pernas cortadas para evitar prejuízo aos seus proprietários. "Sabe que en muchos criadores se inhabilita a las que matan a los fetos golpeándose la panza contra los barrotes, dejando de comer, haciendo lo que sea para que ese bebé no nazca y muera en uno frigorífico" (BAZTERRICA, 2018, p. 35).

Quando as "cabeças" chegam ao ciclo desejado, sâo levadas até a zona de sacrifício. O primeiro passo do processo é o aturdimento, processo delicado em que o aturdidor deve dar um golpe certeiro na fronte, forte o suficiente para desmaiar, mas năo a ponto de matar. A precisâo do golpe interfere diretamente no resultado final da carne. "Se abre una puerta guillotina y entra una hembra desnuda que apenas pasa de los veinte años [...] Sergio levanta la maza y le pega en la frente. Es un golpe seco. Tan rápido y silencioso que es demencial. La hembra se desmaya". (BAZTERRICA, 2018, p. 77). Na sequência, o corpo é levado até outra sala em que ocorre o segundo passo, o degolamento, com a "cabeça" ainda desmaiada. "Con un movimiento rápido le corta el cuello. El cuerpo tiembla un poco. La sangre cae en la cuba [...]" (BAZTERRICA, 2018, p. 82). Quando o corpo se encontra dessangrado, é colocado em um tanque com água fervendo, e em seguida ocorre a retirada de toda a pele.

Em outra sala, a cabeça é cortada e dela săo retirados os olhos, orelhas, língua e cérebro. Já no final do processo "los operarios hacen un corte preciso desde el pubis hasta el plexo solar" (BAZTERRICA, 2018, p. 87). Após a retirada dos órgâos e excrementos, chega-se à parte final, em que se realiza o corte da carne. O trabalho do frigorífico só termina quando "las distintas partes del producto se transportan a los respectivos destinos". (p. 90). Enfim, como destaca a autora, "Todo lo que pasa en la novela pasa hoy, pero se lo hacemos a los animales" (BAZTERRICA, 2018). 


\section{CONSIDERAÇÕES FINAIS}

A literatura, como as demais produçôes humanas, é resultado das condiçôes históricas e materiais de seu tempo. Nesse sentido, o contexto representacional da obra Cadáver Exquisito, ao emular com humanos as condiçōes de produçăo da proteína animal para consumo, adere a diferentes dimensôes da ecopolítica contemporânea, a partir das quais discute tanto a eticidade nas relaçōes atuais entre os humanos e os outros seres vivos quanto tecnologias de controle cada vez mais evidentes nos contextos políticos hodiernos.

À parte, também observamos na obra figuraçôes dos cenários políticos contemporâneos, principalmente quanto a questóes relacionadas às configuraçôes modernas do Estado de Exceçăo e a constituiçăo dos abandonados sociais, dos homines sacri relegados à vida nua, destituída de uma dimensâo jurídica qualificada.

Nesse artigo, a partir dessas observaçōes, visamos apresentar algumas das questôes que constituem o contexto de produçâo da obra, vislumbrando, a partir do externo, evidenciar elementos que caracterizam o romance e, igualmente, participam das condiçōes históricas e materiais que possibilitam a sua apariçâo.

O ponto que mais se destaca como diferenciador da obra está na construçâo de uma distopia que se direciona, sobretudo, a uma particular dimensâo das novas relaçóes entre humanos e ambiente: a alteraçăo no status político dos animais. Como vimos, a insurgência dos direitos dos animais parte da consideraçáo da vida em meio ambiente ecologicamente equilibrado como direito humano, passando pelo ambiente como valor autônomo até chegar às teorias abolicionistas, que auferem o mesmo valor às vidas humanas e às vidas dos outros animais. Nesse ponto, o romance de Agustina Bazterrica náo está sozinho na literatura latino-americana contemporânea, outras obras também se orientam em caminhos semelhantes, como De gados e homens (2013), de Ana Paula Maia, e Jantar Secreto (2016), de Raphael Montes, que perpassam seus enredos por ambientes de abate animal, sendo que o último também aborda a criaçâo de humanos para consumo, embora em uma perspectiva diferente.

Já a outra face do romance, relacionada a noçóes como Estado de Exceçăo, tanatopolítica, vida nua, estados totalitários, tecnologias de vigilância e controle social, aparece de forma mais contundente na literatura latino-americana contemporânea. Desta terra nada vai sobrar, a nâo ser o vento que sopra sobre ela (2019), do brasileiro Ignácio de Loyola Brandăo, A nova ordem (2019), do brasileiro Bernardo Kucinski, Distancia de rescate (2014), da argentina Samanta Schweblin, Nación Vacuna (2017), da argentina Fernanda Garcia Lao, o conto "2035" da obra Sul (2016), da brasileira Verônica Stigger, El tiempo del desierto (2005), do argentino Pedro Mairal, entre outros, sâo distopias (ou obras que dialogam com o gênero) em que figuram, de diferentes maneiras, a forma como o poder, sob uma aparente legitimidade jurídica e/ou em nome de Deus, utiliza-se da política da morte (necropolítica) para determinar quem deve viver e quem deve morrer a fim de atender a interesses que, no fim, podem ser traduzidos em cifras econômicas. 


\section{REFERÊNCIAS}

ARAÚJO, E. A arte da seduçăo: sexualidade feminina na Colônia. In: DEL PRIORE, Mary (org.). História das mulheres no Brasil. Săo Paulo: Contexto, 2015.

BAUN, A. B. A măe do menino, Daniela, Helga e a mulher do moço do saxofone: a representaçăo da mulher em cinco contos de Lygia Fagundes Telles. 2006. 149 f. Dissertaçăo (Programa de Pós-graduaçấo em Letras). Universidade do Paraná, Curitiba, 2006.

BOURDIEU, P. A gênese dos conceitos de habitus e de campo. In: O poder simbólico.

Trad. Fernando Tomaz. 5. ed. Rio de Janeiro: Bertrand Brasil, 2002.

CANDIDO, A. Vários escritos. Săo Paulo: Duas Cidades, 1995.

CANDIDO, A. Literatura e sociedade. Rio de Janeiro: Ouro sobre Azul, 2010.

CASTANHEIRA, C. Conflitos de identidade em "Apenas um saxofone". Revista Interdisciplinar, v. 18, pp. 205-224, 2013.

CHARTIER, R. A história cultural: entre práticas e representaçōes. Rio de Janeiro: Bertrand Brasil, 1991.

DALCASTAGNE, R. Lygia Fagundes Telles e a ambiguidade feminina. Revista Nonada. 9 mar. 2016. Disponível em: http://www.nonada.com.br/2016/03/lygia-fagundes-telles-e-a-ambiguidade-feminina/ Acesso em: 21 jun. 2018.

DEL PRIORE, M. Histórias e conversas de mulher. 2. ed. Sâo Paulo: Planeta, 2014.

DIMAS, A. Garras de Veludo. In: TELLES, L. F. Antes do baile verde. Posfácio de Antonio Dimas. $11^{a}$ reimpressâo. Sáo Paulo: Companhia das Letras, 2009.

RITER, C. A memória da dor: imagens e recorrências em Lygia Fagundes Telles. Ciências e Letras. Porto Alegre, n. 34, pp. 105-118, jul./dez. 2003.

SOIHET, R. Mulheres pobres e violência no Brasil urbano. In: DEL PRIORE, M. (org.). História das Mulheres no Brasil. Săo Paulo: Contexto, 2015.

TELLES, L. F. Antes do baile verde. Posfácio de Antonio Dimas. $11^{a}$ reimpressâo. Sâo Paulo: Companhia das Letras, 2009. 